\title{
Analysis of Water Produced during Thermal Decomposition of Goethitic Iron Ore
}

\author{
Tao Kan, Vladimir Strezov, Tim Evans, and Peter Nelson
}

\begin{abstract}
The aim of this study was to investigate the non-ferrous elemental composition of water produced during thermal decomposition of goethitic iron ore. A typical goethitic iron ore was heated, while the released vapour was condensed by liquid nitrogen trap, and the elements contained in the condensate were measured and grouped. Results showed that Ba in the group of alkali and alkali earth metals, $\mathrm{Mn}, \mathrm{Ni}, \mathrm{Cu}, \mathrm{Zn}$, and $\mathrm{Hg}$ in the group of heavy metals, and $\mathrm{P}$ and $\mathrm{S}$ in the group of non-metal elements were the most abundant elements with present in the chemically bound water. Other technologies including thermogravimetric analysis, Computer Aided Thermal Analysis, and Fourier transform infrared spectroscopy were also used to reveal the thermochemical behaviour of goethite during its thermal processing.
\end{abstract}

Index Terms-Goethite, decomposition, heat of reactions, FTIR.

\section{INTRODUCTION}

The ironmaking industry produces considerable pollutants and greenhouse gas emissions [1], [2]. The increasing environment concerns from this industrial activity have driven research on the chemical nature of the pollution generation and its control and recycling during the iron ore processing.

Non-ferrous elements, such as magnesium $(\mathrm{Mg})$, chromium $(\mathrm{Cr})$, nickel $(\mathrm{Ni})$, mercury $(\mathrm{Hg})$ and lead $(\mathrm{Pb})$ [3] are typically represented in trace concentrations in iron ores [4]. These elements can be released from the iron ores into the atmosphere during thermal processing causing environmental concerns. For example, mercury, a potential neurotoxin, is one of the most toxic trace metals with the possibility of entering human food chain [5]. Selenium, acting as an antioxidant, is one of the essential trace elements, which may become toxic, depending on its oxidation form and quantity [6]. Some elements may have existing or potential applications in other industries, hence their collection maybe economically attractive. Various types of techniques (e.g., gas phase extraction) have been developed to recover the metals from the ores and slags [7].

In this work, goethitic iron ore particles were subjected to thermal processing in a fixed bed reaction system under inert nitrogen atmosphere. The objective of this work was to give an insight into the types and concentrations of non-ferrous

Manuscript received February 10, 2015; revised January 26, 2016. Thi work was supported in part by the Department of Environmental Sciences, Faculty of Science and Engineering, Macquarie University, Sydney NSW 2109, Australia.

The authors are with the Department of Environmental Sciences, Faculty of Science and Engineering, Macquarie University, Sydney NSW 2109, Australia (e-mail: tao.kan@mq.edu.au, vladimir.strezov@mq.edu.au, Tim.Evans@riotinto.com, peter.nelson@mq.edu.au). elements in the produced condensable vapour as well as the thermochemical behaviour of the iron ore during heating. This work provides reference for the processes of iron ore sintering and element recycling.

\section{MATERIALS AND EXPERIMENTAL PROCEDURE}

\section{A. Feedstock}

The iron ore used in this work was goethite $(\mathrm{FeOOH})$ from Western Australia. The iron ore particles were crushed, sieved, and then dried in a vacuum oven at $80^{\circ} \mathrm{C}$ for $1.5 \mathrm{~h}$ to remove the surface moisture.

\section{B. Thermal Processing Experiments}

The water condensate from the decomposition of goethite was conducted in a fixed bed reactor system. High-purity nitrogen with a flow rate of $50 \mathrm{ml} / \mathrm{min}$ swept through the quartz tube fixed bed where the dried goethite particles (0.85-2.8mm) were loaded. The sample was heated to $500^{\circ} \mathrm{C}$ at a heating rate of $20^{\circ} \mathrm{C} / \mathrm{min}$, and then kept at $500^{\circ} \mathrm{C}$ for $2 \mathrm{~h}$. The hot effluent gas from the fixed bed passed through a glass $\mathrm{U}$ tube which was dipped into a cold trap with liquid nitrogen. The moisture and the condensable mass within the effluent were captured in the $U$ tube and then sent for elemental analysis. Around $125 \mathrm{~g}$ of goethite particles were filled into the quartz tube, and about $62 \mathrm{~g}$ of liquid condensate was collected and removed for analysis.

In a paralleled blank experiment aiming at providing a basis for the elements contained in the water, clean quartz fragments were installed to replace the goethite sample. The same amount of deionised water (MilliQ water) as the collected condensate from goethite was injected into the fixed bed at the inlet of the quartz tube, and then carried by the sweeping nitrogen gas.

\section{Elemental Analyses of Goethite and Collected} Condensates

The elemental content of iron ores was analysed using X-Ray fluorescence (XRF) method according to the ISO 9516 standard. Most elements in the condensates were detected according to USEPA 200.8 ICPMS, and the mercury was measured in a standard procedure defined by USEPA245.1 CVAAS.

\section{Thermogravimetric Analysis of Goethite}

Thermogravimetric analysis (TG, model: TGA/DSC 1 STARe System, Mettler Toledo Ltd.) was applied to measure the mass loss of the raw goethite during heating. The sample was continuously heated from room temperature to $1000^{\circ} \mathrm{C}$ under a heating rate of $20^{\circ} \mathrm{C} / \mathrm{min}$, using high-purity nitrogen 
(20 $\mathrm{ml} / \mathrm{min}$ ) as the carrier gas. The obtained TG curve was processed to produce a differential thermogravimetric (DTG, in units of $\mathrm{wt} \% /{ }^{\circ} \mathrm{C}$ ) curve.

\section{E. Computer Aided Thermal Analysis (CATA) of Goethite}

Specific heat of the goethite during heating was measured by a CATA apparatus. It was comprised of an infrared image gold furnace and specially designed internal arrangements as described previously [8]-[10]. Two coaxial quartz tubes with respective diameters of $50 \mathrm{~mm}$ and $13 \mathrm{~mm}$ were installed in the furnace and a graphite tube was placed between the above two quartz tubes. Ultra high-purity argon (Ar) at $5 \mathrm{ml} / \mathrm{min}$ continuously passed through the smaller quartz tube wherein $2.4 \mathrm{~cm}^{3}$ of the goethite was packed. The graphite tube was also flowed by inert Ar gas at $50 \mathrm{ml} / \mathrm{min}$. The furnace was heated from room temperature to $1000^{\circ} \mathrm{C}$ at a heating rate of $20^{\circ} \mathrm{C} / \mathrm{min}$. Three thermocouples were used to log the data of temperatures of the graphite (control temperature) as well as the surface and centre of the goethite sample. The principle and procedure for specific heat calculation was described previously [8].

\section{F. Fourier Transform Infrared Spectroscopy (FTIR) Analysis of Goethite}

The FTIR spectra of goethite and the samples after heating at $500^{\circ} \mathrm{C}$ and $900^{\circ} \mathrm{C}$ were acquired by a FT-IR spectrometer (Model: Nicolet 6700, Thermo Fisher Scientific, Inc.). An attenuated total reflectance (ATR) accessory with a diamond crystal was used for sample analysis.

\section{RESULTS AND DISCUSSION}

The results of elemental analyses of the iron ore, the background test, and the chemically produced water from the decomposition of the goethite iron ore are presented in Table I. All the elements are divided into four groups and listed in order of the atomic weight. For the raw goethite, $\mathrm{Al}, \mathrm{Si}$, and $\mathrm{Fe}$ were the main elements with contents of $0.76,2.07$, and 58.85 $\mathrm{wt} \%$, respectively. The other elements were identified in the raw goethite in very small or trace concentrations.

The elements in the condensate from thermal processing of raw goethite at $500^{\circ} \mathrm{C}$ showed that in the group of alkali and alkali earth metals, $\mathrm{K}$ and $\mathrm{Ba}$ were the two outstanding elements. Among the group of heavy metals, $\mathrm{Mn}, \mathrm{Ni}, \mathrm{Cu}, \mathrm{Zn}$, and $\mathrm{Hg}$ were the most dominant elements identified in the condensate. Among the non-metal elements, the concentrations of $\mathrm{P}$ and $\mathrm{S}$ were significant. The mechanism of deportment of the trace elements from the ore to the condensate during heating could occur via iron ore particle cracking accompanied by the breakage of bonds and functional groups within the particles, releasing moisture, inorganic (e.g., $\mathrm{Hg}$ ), and organic (which probably contains $\mathrm{P}$ or $\mathrm{S})$ vapours.

TABLE I: ELEMENTAL COMPOSITION OF RAW GOETHITE AND CONDENSATES

\begin{tabular}{|c|c|c|c|c|}
\hline \multicolumn{2}{|c|}{ Elements } & \multirow{2}{*}{$\begin{array}{c}\text { Goethite (wt\%.) } \\
0.7571\end{array}$} & \multirow{2}{*}{$\begin{array}{c}\text { Condensate from blank experiment } \\
\text { (ug/L) }\end{array}$} & \multirow{2}{*}{$\begin{array}{c}\text { Condensate from } 500{ }^{\circ} \mathbf{C} \text { heating of goethite } \\
(\mathbf{u g} / \mathbf{L})\end{array}$} \\
\hline Main elements & $\mathrm{Al}$ & & & \\
\hline & $\mathrm{Si}$ & 2.072 & 2900 & 2100 \\
\hline & $\mathrm{Fe}$ & 58.85 & 43 & 59 \\
\hline \multirow{5}{*}{$\begin{array}{l}\text { Alkali and alkali } \\
\text { earth metals }\end{array}$} & $\mathrm{Na}$ & $<0.01$ & 5.4 & 6.9 \\
\hline & $\mathrm{Mg}$ & 0.042 & 0.13 & 0.3 \\
\hline & $\mathrm{K}$ & 0.0042 & 0.058 & 0.37 \\
\hline & $\mathrm{Sr}$ & $<0.001$ & $<1$ & 1.3 \\
\hline & $\mathrm{Ba}$ & $<0.01$ & $<1$ & 14 \\
\hline \multirow[t]{7}{*}{ Heavy metals } & $\mathrm{Cr}$ & $<0.001$ & $<1$ & 2.9 \\
\hline & $\mathrm{Mn}$ & 0.04 & 1.5 & 24 \\
\hline & $\mathrm{Ni}$ & 0.003 & 1.3 & 29 \\
\hline & $\mathrm{Cu}$ & 0.003 & 8.5 & 95 \\
\hline & $\mathrm{Zn}$ & $<0.001$ & 9.2 & 91 \\
\hline & $\mathrm{Cd}$ & I & $<0.1$ & 0.48 \\
\hline & $\mathrm{Pb}$ & $<0.001$ & $<1$ & 3.6 \\
\hline \multirow{4}{*}{$\begin{array}{l}\text { Non-metal } \\
\text { elements }\end{array}$} & B & 1 & 1100 & 980 \\
\hline & $\mathrm{P}$ & 0.053 & 0.096 & 0.14 \\
\hline & $\mathrm{S}$ & 0.011 & 0.76 & 1.8 \\
\hline & As & 0.001 & 24 & 23 \\
\hline
\end{tabular}

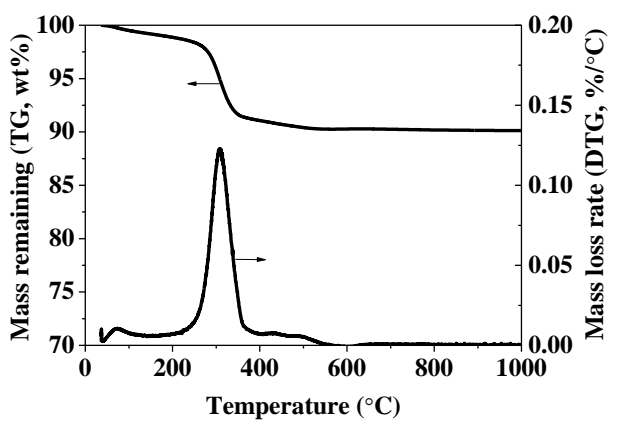

Fig. 1. TG and DTG curves of raw iron ore at the heating rate of $20{ }^{\circ} \mathrm{C} / \mathrm{min}$.
The superimposed mass (TG) and mass loss rate (DTG) data for the raw goethite at the heating rate of $20^{\circ} \mathrm{C} / \mathrm{min}$ are shown in Fig. 1.

According to the TG curve, $90.1 \mathrm{wt} \%$ of the iniital mass remanied at the final temperature of $1000^{\circ} \mathrm{C}$. The iron ore mass loss went through three main discrete stages of decomposition. During the first stage (room temperature to $150^{\circ} \mathrm{C}$ ), a small peak centring at around $70-80^{\circ} \mathrm{C}$ indicates the evaporation of the bound water.

The second stage ranging from $150^{\circ} \mathrm{C}$ to $500^{\circ} \mathrm{C}$ is responsible for the main mass loss of the sample. The sharp peak centring at $310^{\circ} \mathrm{C}$ was associated with the 
decomposition of the goethite during heating, with a maximum mass change rate of $0.12 \mathrm{wt} \% /{ }^{\circ} \mathrm{C}$. The main contributor to the loss of weight during heating, as shown in Fig. 1 was the production of water as a product of decomposition, which was analysed in this research. The water is produced with dehydroxylation of the goethite expressed with equation $2 \mathrm{FeOOH} \rightarrow \mathrm{Fe}_{2} \mathrm{O}_{3}+\mathrm{H}_{2} \mathrm{O}$. During the third stage (after $500{ }^{\circ} \mathrm{C}$ ), the mass of residual solid continuously decreased at a very slow rate.

The change in specific heat $\left(C_{p}\right)$ of the goethite with temperature at a heating rate of $20^{\circ} \mathrm{C} / \mathrm{min}$ is shown in Fig. 2.

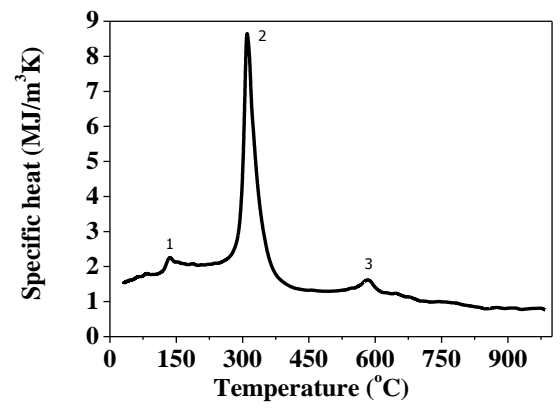

Fig. 2. Specific heat during thermal processing of iron ore at the heating rate of $20^{\circ} \mathrm{C} / \mathrm{min}$.

Three positive peaks were identified. Each peak on the $\mathrm{Cp}$ curve was then integrated by connecting the peak start temperature (Ts) and the end temperature (Te) of and the volumetric heat of reaction $(\Delta \mathrm{Hv})$ was thus determined. The integration results are shown in Table II.

The specific heat of the goethite at room temperature was 1.5 MJ $/ \mathrm{m}^{3} \mathrm{~K}$. The initial small endothermic peak between 96 and $174{ }^{\circ} \mathrm{C}$ corresponded to the peak No.1 of dehydration in Table II with a mass loss percent of $1.08 \mathrm{wt} \%$. The most outstanding and sharp endothermic peak (peak No.2) between 212 and $424^{\circ} \mathrm{C}$ centring at $310.2^{\circ} \mathrm{C}$ was ascribed to the dehydroxylation reaction with a reaction heat of 258.41 $\mathrm{MJ} / \mathrm{m}^{3}$. This reaction corresponded to the main sharp peak centring at $310^{\circ} \mathrm{C}$ in the DTG curve in Fig. 1, and was responsible for the main mass loss percent of $8.38 \mathrm{wt} \%$. The $3^{\text {rd }}$ endothermic peak followed in the temperature range of $532-618^{\circ} \mathrm{C}$ and was the indication of reaction of clay decomposition. This resulted in a minor mass loss of only $0.41 \mathrm{wt} \%$. After $620^{\circ} \mathrm{C}$, as shown in Fig. 2, no obvious peaks appeared. Mass loss in Table II was calculated from the TG data and based on the mass of raw goethite.

TABLE II: REACTION HEATS DURING THERMAL PROCESSING OF GOETHITE AT THE HEATING RATE OF $20^{\circ} \mathrm{C} / \mathrm{MIN}$

\begin{tabular}{rccccc}
\hline $\begin{array}{l}\text { Peak } \\
\text { No. }\end{array}$ & Reaction type & $\begin{array}{l}\mathbf{T}_{\mathbf{s}} \\
\left.\mathbf{(}^{\mathbf{0}} \mathbf{C}\right)\end{array}$ & $\begin{array}{l}\mathbf{T}_{\mathbf{e}} \\
\left.\mathbf{(}^{\mathbf{0}} \mathbf{C}\right)\end{array}$ & $\begin{array}{l}\Delta \mathbf{H v} \\
\left(\mathbf{M J} / \mathbf{m}^{\mathbf{3}}\right)\end{array}$ & $\begin{array}{l}\text { Mass loss } \\
(\mathbf{w t} \%)\end{array}$ \\
\hline 1 & Dehydration & 96 & 174 & 7.91 & 1.08 \\
2 & $\begin{array}{c}\text { Dehydroxylation } \\
\text { Clay }\end{array}$ & 212 & 424 & 258.41 & 8.38 \\
3 & 532 & 618 & 15.39 & 0.41 \\
\hline \hline
\end{tabular}

FT-IR analysis (see Fig. 3) was used to investigate the chemical functional groups existing in the raw goethite (curve A) as well as the produced solid after heating to $500^{\circ} \mathrm{C}$ (curve B).

For the IR spectrum of the raw goethite, the minor peaks between 3560 and $3750 \mathrm{~cm}^{-1}$ (such as $3694 \mathrm{~cm}^{-1}$ ) and the obvious peaks in the range of $950-1200 \mathrm{~cm}^{-1}(1095,1033$, and $1007 \mathrm{~cm}^{-1}$ ) correspond to the aluminosilicate clays such as kaolinite [11]. The broad band at $3097 \mathrm{~cm}^{-1}$ is due to the stretching vibration of the $\mathrm{OH}$ group and the bonded water [12]. The small peak at $1633 \mathrm{~cm}^{-1}$ is associated to the bending of $-\mathrm{OH}$ [13], [14]. The two sharp peaks at 885 and $796 \mathrm{~cm}^{-1}$ correspond to the vibrations of $\mathrm{O}=\mathrm{Fe}-\mathrm{O}-\mathrm{H}$ [12], [14]. The small peak at $526 \mathrm{~cm}^{-1}$ should be ascribed to the presence of small amount of hematite $\left(\mathrm{Fe}_{2} \mathrm{O}_{3}\right)$.

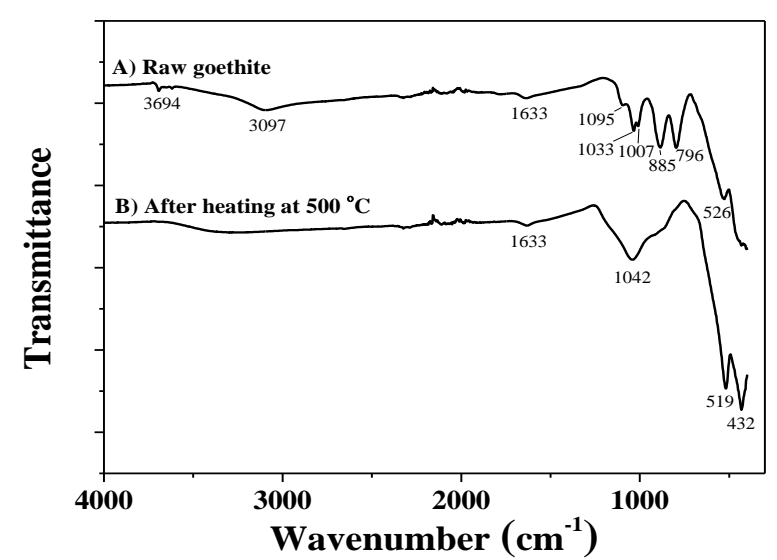

Fig. 3. FTIR spectra of raw goethite and thermally processed goethite at $500{ }^{\circ} \mathrm{C}$.

The FTIR spectra of the sample heated to $500^{\circ} \mathrm{C}$ (curve B in Fig. 4) exhibited broad absorption band between 2900 and $3700 \mathrm{~cm}^{-1}$ indicating presence of small amount of $\mathrm{OH}$ group and bonded water, which is much lower than the corresponding broad band for the raw goethite. After heating at $500^{\circ} \mathrm{C}$, the appearance of single peak at $1042 \mathrm{~cm}^{-1}$ relates to the asymmetric stretch of the $\mathrm{Si}-\mathrm{O}-\mathrm{Al}$ framework, which is accompanied by the disappearance of the peaks at 1095, 1033, and $1007 \mathrm{~cm}^{-1}$. This is due to the decomposition of aluminosilicate clays. The appearance of two sharp peaks at 519 and $432 \mathrm{~cm}^{-1}$ are associated with the formation of hematite $\left(\mathrm{Fe}_{2} \mathrm{O}_{3}\right)$ [12].

\section{CONCLUSIONS}

In this study, a typical goethitic iron ore was heated under inert nitrogen atmosphere to collect the released vapour, which was then condensed by liquid nitrogen trap and subjected to elemental analysis. Thermochemical characteristics of goethite during its thermal processing were also investigated by various technologies. Results indicated that $\mathrm{Ba}, \mathrm{Mn}, \mathrm{Ni}, \mathrm{Cu}, \mathrm{Zn}, \mathrm{Hg}, \mathrm{P}$, and $\mathrm{S}$ were the most represented elements with higher concentrations in the condensate. Three main reactions occurred during the heating of goethite with the volumetric reaction heats of 7.91, 258.41, and $15.39 \mathrm{MJ} / \mathrm{m}^{3}$. The decomposition of goethite occurred in the temperature range of $212-424^{\circ} \mathrm{C}$ (peak $\mathrm{T}$ at $310^{\circ} \mathrm{C}$ ) and was responsible for the maximum sample mass loss rate of $0.12 \mathrm{wt} \% /{ }^{\circ} \mathrm{C}$. Results of Fourier transform infrared spectroscopy also reflect the changes of functional groups during the heating of goethite.

\section{ACKNOWLEDGEMENTS}

The research was conducted with financial support from 
the Australian Research Council (grant no: LP140100182), Hamersley Iron and Macquarie University Outside Study Program.

\section{REFERENCES}

[1] T. E. Norgate, S. Jahanshahi, and W. J. Rankin, J Clean Prod, vol. 15, p. 838, 2007.

[2] D. B. Korol, J Clean Prod, vol. 54, p. 235, 2013.

[3] K. A. Akinade, R. M. Campbell, and D. A. C. Compton, J Mater Sci, vol. 29, p. 3802, 1994.

[4] M. Alvarez, E. E. Sileo, and E. H. Rueda, Chem Geol, 2005, vol. 216, p. 89, 1994.

[5] P. Shah, V. Strezov, K. Prince, and P. F. Nelson, Fuel, vol. 87, p. 1859, 2008.

[6] P. F. Nelson, P. Shah, V. Strezov, B. Halliburton, and J. N. Carras, Fuel, vol. 89, p. 810, 2010.

[7] Y. Chen, E. R. M. Mariba, L. V. Dyk, and J. H. Potgieter, Int J Min Process, vol. 98, p. 1, 2011.

[8] V. Strezov, J. A. Lucas, and L. Strezov, J. Therm. Anal. Calorim., vol. 72 , p. 907,2003

[9] V. Strezov and T. J. Evans, Int. J. Food Prop., vol. 8, p. 101, 2005.

[10] V. Strezov, B. Moghtaderi, and J. A. Lucas, J. Therm. Anal. Calorim. vol. 72, p. 1041, 2003.

[11] J. Kristof, R. L. Frost, A. Felinger, and J. Mink, J Mol Struct, vol. 410, p. 119, 1997.

[12] V. Strezov, A. Ziolkowski, T. J. Evans, and P. F. Nelson, J Therm Anal Calorim, vol. 100, p. 901, 2010.

[13] P. S. R. Prasad, K. S. Prasad, V. K. Chaitanya, E. V. S. S. K. Babu, B Sreedhar, and S. R. Murthy, J Asian Earth Sci, vol. 27, p. 503, 2006.

[14] X. M. Rong, W. L. Chen, Q. Y. Huang, P. Cai, and W. Liang, Colloid Surface B, vol. 80, p. 79, 2010.

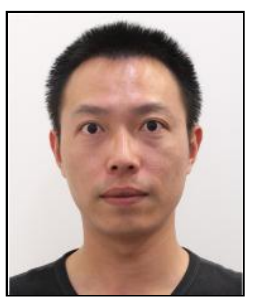

Tao Kan began his consecutive master and Ph.D study in chemistry in 2004 and was awarded the Ph.D degree in physical chemistry from the University of Science and Technology of China, Hefei City, Anhui Province, China. During 2004-2010, his research mainly focused on the bio-fuels production from biomass.

He worked as Postdoctoral Fellow in the Institute of Process Engineering, Chinese Academy of Sciences, Beijing, China during 2010-2012 in the field of catalytic hydroprocessing of middle-temperature coal tar and ethylene tar to generate gasoline and diesel. From 2012, he has been working as a Research Fellow in Macquarie University, Sydney, Australia. His research interests are currently biomass pyrolysis and thermal processing of iron ore to investigate the physicochemical behaviour of ore particles and the relevant environmental aspects.

Dr Kan has made more than 20 research articles published in international journals and conferences such as Fuel, Journal of Cleaner Production, and Energy \& Fuels.

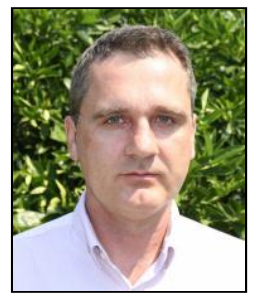

Vladimir Strezov completed his $\mathrm{PhD}$ in chemical engineering at the University of Newcastle, Australia where he jointly worked with the pyrometallurgy research team of BHP Research Laboratories. Before joining Macquarie University in 2003 he was a research associate and laboratory manager at the University of Newcastle. He is currently Professor at the Department of Environmental Sciences, Faculty of Science and Engineering, Macquarie University, Australia.

Prof. Strezov's current research projects are concerned with improvement of energy efficiency and reduction of emissions in minerals processing, electricity generation and production of biofuels. He has established close links with several primary industries leading to successful joint projects in the field of energy and sustainability. He currently manages a laboratory for thermal and environmental processing funded in collaboration with the Rio Tinto Group.

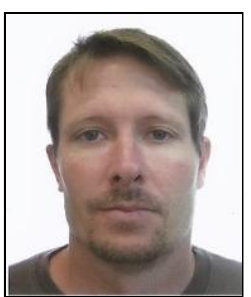

Tim Evans is Adjunct Professor at the Faculty of Science and Engineering, Macquarie University (Sydney, Australia) and Principal Engineer at Rio Tinto. He has a long association with Australian primary industries, such as BHP Billiton, HIsmelt and Rio Tinto. He holds $\mathrm{PhD}$ in Chemical engineering from the University of Newcastle. Dr Evans' expertise is in energy transformation and mineral processing, specifically high temperature industrial processing.

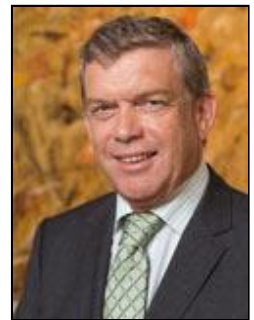

Peter Nelson is currently appointed Professor of Environmental Studies, and Pro Vice-Chancellor (Research Performance and Innovation) at Macquarie University, Sydney, Australia. He was previously Senior Principal Research Scientist in CSIRO (Commonwealth Scientific and Industrial Research Organisation of Australia) Energy Technology, where he managed projects on energy and the environment, air pollutant measurement, mechanism of formation and control.

Professor Nelson has more than 30 years' experience in the assessment and control of pollution as well as environmental issues associated with energy use, e.g., toxic organics from industrial and vehicular sources, trace elements and waste management. His research outputs have resulted in $>200$ peer-reviewed journal and conference papers and reports for government and industry. Much of his work was done in close co-operation with industry (e.g., RioTinto; Australian Coal Association Research Program and New South Wales Power Generators) or government (eg, with the Australian Greenhouse Office; Department of Environment Water Heritage \& the Arts, New South Wales Department of Environment Climate Change \& Water) 